\title{
LEGUMES IN SOIL FERTILITY MANAGEMENT: THE CASE OF PIGEONPEA IN SMALLHOLDER FARMING SYSTEMS OF ZIMBABWE
}

\author{
P. MAPFUMO, B.M. CAMPBELL', S. MPEPEREKI and P. MAFONGOYA ${ }^{2}$ \\ Department of Soil Science and Agricultural Engineering, University of Zimbabwe, P.O. Box MP 167, Mt \\ Pleasant, Harare, Zimbabwe \\ ${ }^{1}$ Institute of Environmental Studies, University of Zimbabwe, P.O. Box MP 167, \\ Mt Pleasant, Harare, Zimbabwe \\ ${ }^{2}$ ICRAF-Zambia, P O Box 510046, Chipata, Zambia
}

(Received 20 March, 2000; accepted 15 May, 200I)

\begin{abstract}
We investigated the current use of legumes in soil fertility management and the feasibility of promoting use of pigeonpea in smallholder farming systems of a Communal Area in Northeast of Zimbabwe. Participatory rural appraisal methods were used to establish farmer management strategies and perceptions on major constraints to crop productivity. Soil fertility parameters were evaluated through farmer participatory experiments. The study revealed limited cultivation of legumes for both human nutrition and soil fertility management. Legumes were generally regarded as women's crops, and therefore minor, because of men's domination over women in the household decision-making process. Balancing gender interests in terms of allocation of inputs and distribution of benefits at household level was identified as a major challenge to the implementation of legume technologies. Poor extension thrusts with respect to legume production, and poor agronomic practices were identified as major production constraints. Over-emphasis on maize in the current extension packages led to the relegation of legumes to the status of 'minor crops'. Participatory experiments suggested that pigeonpea can be successfully grown by farmers under poor soil fertility conditions. The crop yielded about 3 to 9 tha $^{-1}$ of shoot biomass in a single cropping season, and up to $23 \mathrm{t} \mathrm{ha}^{-1}$ after two seasons of growth. High amounts leaf litter released by the crop in one season (up to $3 \mathrm{t} \mathrm{ha}^{-1}$ ) are considered a potentially viable source of nutrients for subsequent crops, as confirmed by a $22 \%$ maize yield increase obtained from a field that was previous cultivated with pigeonpea.
\end{abstract}

Key Words: Cajanus cajan, farmer participatory experiments, leaf litter, nutrient replenishment, Zimbabwe

\section{RÉSUMÉ}

Les investigations sur l' utilisation des légumineuses dans la gestion de fertilité du sol ainsi que les possibilités d' incorporer le pois cajan dans le système agricole de petits fermiers ont été fait dans un milieu rural au NordEst du Zimbabwe. La méthode "Participatory rural appraisal" a été utilisée pour déterminer les stratégies de gestion du sol et les perceptions qui contribuent à la réduction de la productivité de la récolte. Les paramètres de fertilité du sol ont été analysés en collaboration avec des agriculteurs. Cette étude a révelé qu' il y a une utilisation limitée de légumineuses dans l' alimentation des gens ainsi que dans la gestion de fertilité du sol. Les légumineuses sont géneralement considérées commes la récolte pour les femmes, sur ce, de peu d' importance, et à cause de la domination des hommes dans la prise de décision dans le foyer. L'exécution des téchnologies d' incorporer les légumineuses dans le système de production agricole s' est heurtée à un problème majeur de domination de l'homme, ses préférences dans la répartition et la distributions des intrants et les bénéfices. Un autre problème identifie, c'est une vulgarisation très limitée de la production de légumineuses et une difficile adaptation agronomique de variétés de légumineuses qui sont déjà dans le système. Le système de vulgarisation existant s'est 
concentré plus sur la production du maïs, ce qui a mené à considérer les lègumineuses commes les plantes de moins d' importance. Les expériences participatives ont suggeré que le pois cajan peut être produit par les fermiers dans des sols moins fertiles. La production a été estimée de 3 à $9 \mathrm{t} \mathrm{ha}^{-1}$ de biomasse dans une seule saison de production, et de $23 \mathrm{t} \mathrm{ha}^{-1}$ après deux saisons. Une quantité considérable de litière de feuilles venant de plantes dans une seule saison (jusqu'a $3 \mathrm{t} \mathrm{ha}^{-1}$ ) est considéree comme une source importante de nutriments pour les plantes consécutives, comme l' augmention de $22 \%$ de production de maïs l'a confirmé après une culture de pois cajan.

Mots Clés: Cajanus cajan, essais participatifs des fermiêrs, litière de feuille, restauration des nutriments, Zimbabwe

\section{INTRODUCTION}

The improvement of soil fertility in smallholder farming systems in semi-arid and sub-humid Africa has, over the years, been rendered more difficult and complicated due to increasing scarcity of locally-derived nutrient sources and the changing socio-economic environment (Breman, 1998). The major nutrient sources traditionally used by farmers, which include manure, woodland leaf litter and termitarium soil, are largely derived from common pool resources (Swift et al., 1989; Campbell et al., 1993). However, the rising human population pressure has caused a rapid disappearance of such resources, including loss of grazing areas, as cultivated lands continue to expand (Whitlow, 1980; Campbell, 1994). Although cattle manure remains the most commonly used organic fertiliser, it has a poor capacity to supply $\mathrm{N}$ and is only available to about $50 \%$ of the households in the smallholder farming sector (Grant, 1967; Waeterloos et al., 1993; Mugwira and Murwira, 1997). As in other parts of Africa (Sanchez and Logan, 1992), N is the most limiting crop nutrient in the Zimbabwean smallholder farming sector (Grant, 1981; Mapfumo and Mtambanengwe, 1999). The use of mineral fertilisers in African agriculture in very limited (Prins and van Reuler, 1993), and Zimbabwe is no exception. The removal of subsidies on mineral fertilisers as part of the economic structural adjustment programme has rendered the fertilisers unaffordable to most smallholder farmers in Zimbabwe. Farmers, because of unreliabic rainfall in some areas, have also considered the use of mineral fertiliser risky. Nitrogen-fixing legumes can play a complementary or alternative role as sources of organic fertiliser in these farming systems.
Research in many parts of the tropics, including Southern Africa, has demonstrated that legumes have the potential to sustain soil fertility in smallholder farming systems (Giller et al., 1994; Kumwenda et al., 1995). Pigeonpea [Cajanus cajan (L.) Millsp.] has been considered a potential crop in this respect because of its adaptability to semi-arid environments, tolerance to low soil fertility and capacity to recycle nutrients (Whiteman et al., 1985; Nene and Sheila, 1990; Mapfumo et al., 1998). Pigeonpea grain contains an average of $22 \%$ crude protein and has a high nutritional value for both humans and livestock. Despite the well-known role of pigeonpea in subsistence agriculture in Asia and parts of Africa (Whiteman et al., 1985; Ali, 1996), the crop has not been exploited in Zimbabwe. In the semi-arid tropics of Asia pigeonpea- and soyabean-based systems are rapidly replacing other systems because of higher monetary returns (Ali, 1996). Conservative estimates from Kenya, Malawi, Mozambique and Tanzania show that pigeonpea is cropped on $300000-500000$ ha (Tuwafe et al., 1994). In Zimbabwe, the area cropped to this legume is currently negligible. However, FSRU (1994) reported that $30 \%$ of the arable land in smallholder farming systems of Zimbabwe is fallowed in any one cropping season due to depleted soil fertility. Legumes adaptable to poor soil fertility, such as pigeonpea, could therefore be grown on a significant proportion of this area.

In most parts of Southern Africa, efforts are being made to investigate the current and potential role of legumes as a direct method of addressing the soil fertility problem in smallholder farming systems. Recent research work in Zimbabwe has revealed the major soil fertility management practices, major nutrient sources and constraints, and how these are affected by resource 
endowments of households (FSRU, 1993; Carter and Murwira, 1995; Campbell et al., 1998). It is, however, not clear how much the farmers value the role of legumes in soil fertility management and the determinants for the adoption of legumes by farmers are not well known. Do legumes such as pigeonpea really have a place in these farming systems? To address these questions and complement regional efforts to promote legume technologies, a farmer participatory study was conducted in Murewa Communal Area in Northeast Zimbabwe. The study had two specific objectives: i) to investigate the current role of legumes in soil fertility management; and ii) to identify opportunities for pigeonpea as a soil improving crop through farmer-led experimentation.

\section{MATERIALS AND METHODS}

The study was conducted in Mukarakate East and West Wards (rural development units) of Murewa Communal Area, in Northeast Zimbabwe (17 45'S; $31^{\circ} 45^{\prime} \mathrm{E}$ ), between 1996 and 1998. The study was in two parts. In the first part, study objectives were pursued using participatory rural appraisal (PRA) techniques (Thies and Grady, 1991; Chambers, 1992). The second part was based on farmer-managed experiments in which pigeonpea productivity and residual effects on a subsequent maize crop were determined, and farmer management techniques monitored. There was minimal interference from the researchers in these trials.

Investigation of the current role of legumes. The PRA was carried out at two main levels. The first involved community leaders while the second involved the general community.

Community leaders' meeting. A meeting was convened involving village heads, extension workers from the national Agricultural Technical and Extension Service (AGRITEX) and other community leaders. A semi-structured interview was conducted to investigate factors affecting agricultural production in the area. Major contrasting features between modern and traditional soil fertility management practices, as perceived by farmers, were also explored.
Community meeting. About 76 farmers participated in the PRA group meetings in Mukarakate West Ward and 44 in Mukarakate East Ward. In each Ward, farmers formed groups consisting of people with a good knowledge of each other's social situation from two or three villages. For each village, men and women were requested to produce separate resource maps. This ensured equal participation by both gender, and helped to reveal any differences in their perceptions on resource utilisation. Each group was given a chance to present its map outputs. The mapping exercise was followed by construction of linkage diagrams showing the crops grown and the nutrient sources used. The crops and nutrient sources were then ranked by order of importance using pairwise ranking. Direct matrix ranking techniques were used to determine how farmers distribute the available nutrient sources among crops. Attributes on why farmers came up with a particular order of ranking were generated through an interactive debate with farmers during the ranking exercise. More information was generated in an overall discussion session during which different groups of farmers presented their outputs. Major soil factors affecting crop productivity were also discussed. Efforts were made to identify possible solutions to some of the problems presented.

Farmer experimentation. In the final stages of the PRA exercise, pigeonpea was introduced to the farmers. Photographs of the crop in its different growth stages were used as aids. Most farmers had seen pigeonpea from an agroforestry project previously conducted in the area and this made its introduction relatively easy. Seven volunteer farmers were given long duration seed, variety Ex-Malawi, obtained from National Tested Seeds (Pvt) Ltd in Harare. The farmers were included as an additional group to 13 farmers who hosted researcher-managed experiments which were concurrently initiated in the area (Mapfumo et al., 1998). After some preliminary agronomic guidelines, the farmers grew the pigeonpea during the 1996/97 season, and were left to independently manage the crop throughout the growing season. Planted areas ranged from 0.1 to 0.4 ha in size. Occasional field visits were made to enable monitoring of farmers' management techniques 
and timing, including planting method and spacing, weeding patterns and preference for final crop utilisation. At each farm, the soils were characterised for physical and chemical properties at the start of the experiment. Pigeonpea plantings were done during last week of December in the $1996 / 97$ season. A spacing of $40-45 \mathrm{~cm}$ inter-row and $20 \mathrm{~cm}$ within row was used $(\mathrm{cf} .90 \mathrm{~cm} \times 20 \mathrm{~cm}$ recommended by researchers). Farmers preferred a spacing that they were already using for other legumes. All farmers weeded their first season crops between 2 and 4 weeks after emergence while crops in their second year were never weeded, except in the case of two farmers who weeded their crops once in the second season (just before flowering). Pigeonpea shoot biomass was determined at physiological maturity.

The experiment was repeated during the 1997/ 98 season, but farmers were requested to use different plots. Planting was done during the first week of December. Four farmers decided to retain part of their original plots (30-50\%) in addition to the new plots. The same field measurements were also taken for the resultant two-year crop. Amount of cumulative litterfall (leaves + petioles) was determined during the growing season through periodic sampling. Grain yields were not determined because some farmers had harvested the grain for consumption before the scheduled sampling date.

Pigeonpea plots harvested during the 1996/97 season were planted to maize in the $1997 / 98$ season. Through researcher intervention, adjacent plots that were under maize in the 1996/97 season were also retained and considered as control treatments. Maize yields from the two treatments (i.e., maize-maize and pigeonpea-maize) were determined at the end of the season on a whole plot basis. The data were explored using MINITAB Release 8.3 descriptive statistical tools and mean comparisons made using t-test statistic.

\section{RESULTS}

The PRA survey was able to capture community views on the exten! and severity of soil fertility problems, as well as the current practices and strategies employed by farmers in managing these constraints.
Community leaders' view. Poor soil fertility was seen as a problem that was more serious than perceived by researchers and other outsiders. The leaders shared the view that most soils were just too exhausted for any meaningful crop production (ivhu ranyanya kusakara), and generally believed that use of inorganic fertilisers contributed to this decline in soil productivity. It was felt that the soil fertility management practices that were currently recommended (mineral N, P and K), did not ensure a long term nutrient investment in soils. They felt that there should be ways to ensure good yields (particularly with maize), even without applying any fertiliser, as was the case many years ago (e.g., in the 1940's). Use of sunnhemp (Crotalaria spp.) as a green manure during the 1940's was noted. Cessation of this practice was attributed to the shift of emphasis to inorganic fertilisers. The leaders believed that the majority of farmers had the capacity to learn and adopt new technologies, but were worried about the lack of follow-up activities from researchers.

\section{Availability and distribution of natural} resources. The resource maps produced by farmers showed land use, soil types, woodlots and basic infrastructure (Figs. 1 and 2). Woodlots were always emphasised on the maps, and farmers cited firewood as a major problem. Unlike their male counterparts, women farmers particularly highlighted indigenous fruit trees in both arable and non-arable areas (Fig. 1). Soils were classified as predominantly sandy in Mukarakate West (jecha/shapa) and sandy to sandy loams (ivhu ramapfuti) in Mukarakate East. The soils in Mukarakate East also included bands of reddishbrown sandy clay loams (mhukutu) derived from intrusive dolerite. Grazing areas were predominantly located on depleted and abandoned fields or close to rivers. The maps also showed that some trees are commonly left in the fields. These included Parinari curatellifolia, Brachystergia spiciformis, Julbernardia globiflora, Uapaca kirkiana and Strychnos spinosa. The trees are usually left for shade, firewood, poles and fruit production.

Commonly grown crops in the survey area. Tables 1 and 2 show the major crops grown in the 


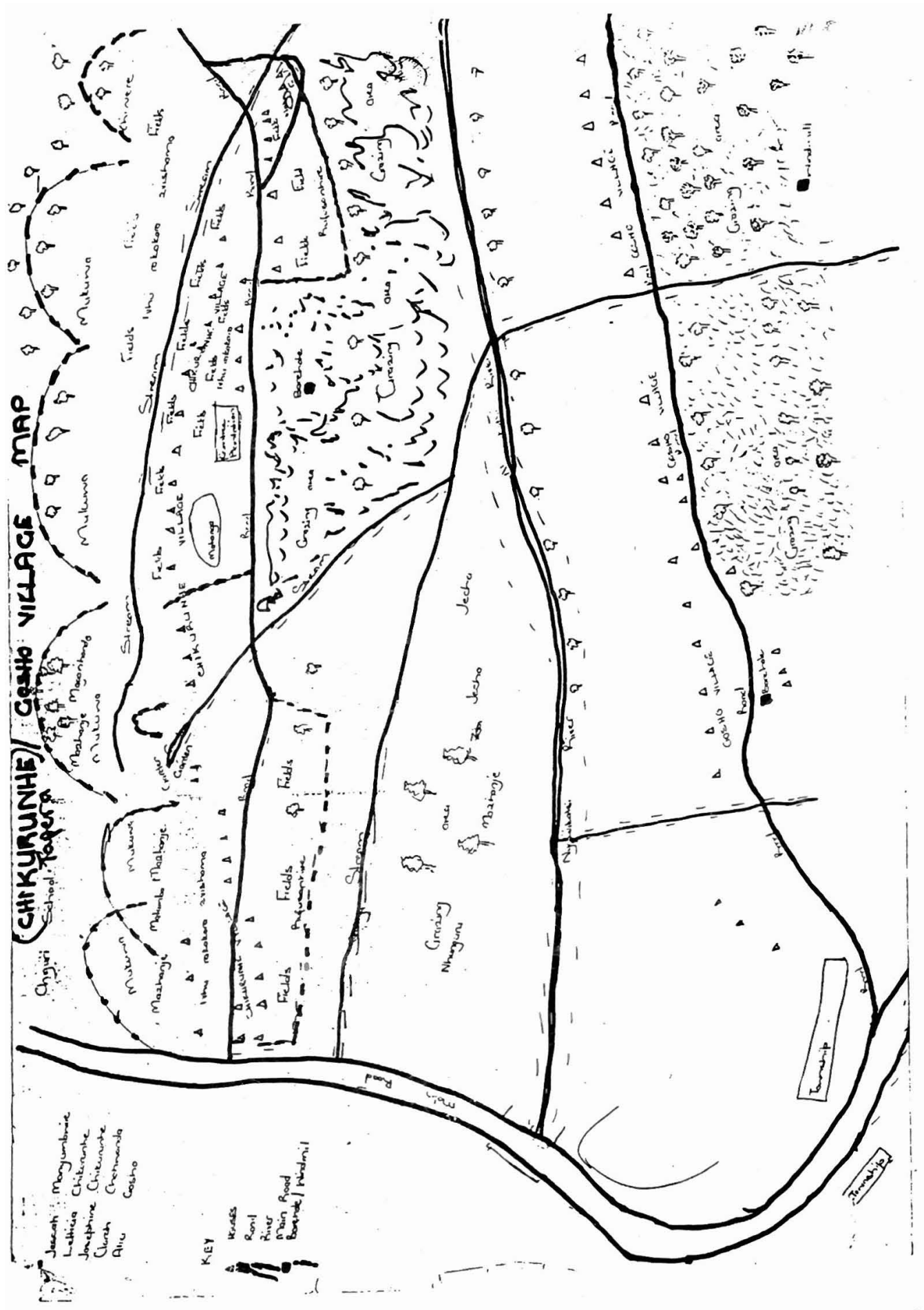

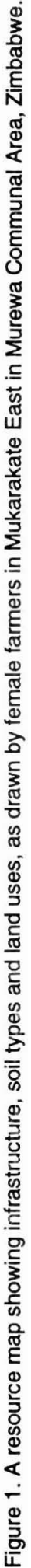




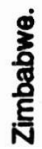
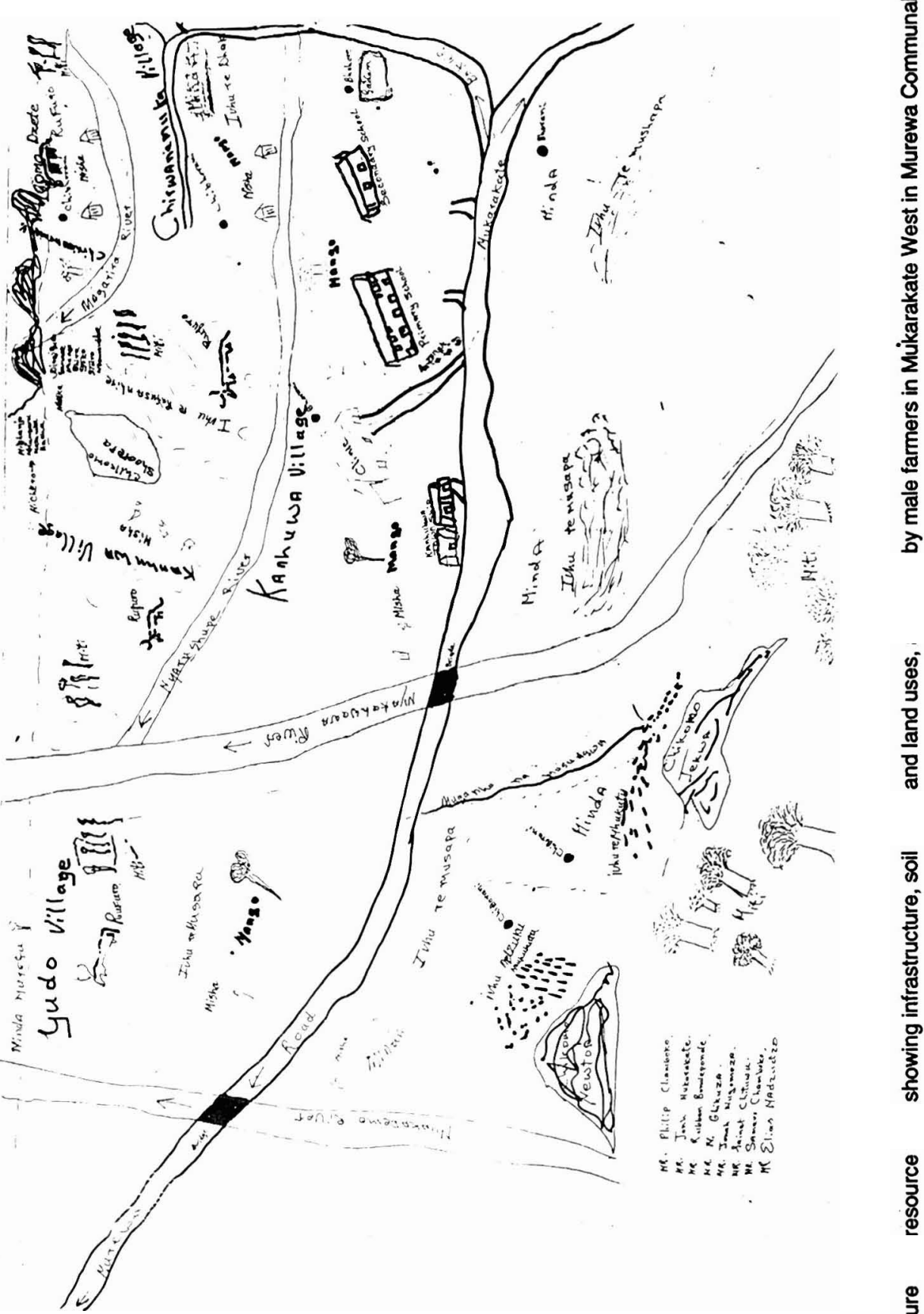

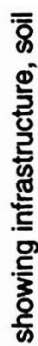

익

온 
TABLE 1. Type of crops grown by farmers in Mukarakate East Ward of Murehwa Communal Area, and how they were ranked by male and female farmers

\begin{tabular}{|c|c|c|c|c|c|}
\hline \multicolumn{3}{|r|}{ Men $(n=28)$} & \multicolumn{3}{|c|}{ Women $(n=16)$} \\
\hline Crop & Ranking & Reason for preference, and other attributes & Crop & Ranking & Reason for preference, and other attributes \\
\hline Maize & 1 & staple food, cash, easy to grow, grown by everyone & $\begin{array}{l}\text { Maize } \\
\text { Sunflower }\end{array}$ & $\begin{array}{l}1 \\
2\end{array}$ & $\begin{array}{l}\text { cash, sadza-staple food, green mealies } \\
\text { needs little fertiliser, quick cash, oil }\end{array}$ \\
\hline Rapoko & 2 & $\begin{array}{l}\text { pivotal in family food security, stores longer, } \\
\text { beer, sadza, used during rituals }\end{array}$ & $\begin{array}{l}\text { Groundnut } \\
\text { Field beans }\end{array}$ & $\begin{array}{l}3 \\
4\end{array}$ & $\begin{array}{l}\text { peanut butter for consumption and sale, yields are low } \\
\text { cash, relish, can be grown twice per season, seed } \\
\text { availability a problem }\end{array}$ \\
\hline Cotton & 3 & cash, benefits those on heavier soils & & & \\
\hline Groundnut & 4 & peanut butter, grown year after year even if it fails & $\begin{array}{l}\text { Cotton } \\
\text { Cowpea }\end{array}$ & $\begin{array}{l}5 \\
5\end{array}$ & $\begin{array}{l}\text { cash, high input e.g. pesticides hard to get } \\
\text { food/relish, cash, they mature early }\end{array}$ \\
\hline Cowpea & 5 & $\begin{array}{l}\text { does not require extra land (intercropped - } \\
\text { although Agritex does not recommend), relish (leaf \& } \\
\text { grain), easy to grow }\end{array}$ & Bambara nut & 6 & food, cash, ripen fast \\
\hline Sorghum & 5 & sadza, grown by a few - most prefer maize & & & \\
\hline Bambara nut & 8 & grown by a few & & & \\
\hline Field bean & * & & & & \\
\hline
\end{tabular}

* = not part of the list 
two Wards and how they were ranked by farmers. The only legume regarded as a major crop is groundnut (Arachis hypogea L.) and, to a lesser extent, cowpea (Vigna unguiculata [L.] Walp). Farmers in Mukarakate West Wards, however, reported very poor groundnut performance on their soils, unless it was grown on a relatively fertile piece of land (dzinoramba turi tudikidiki twakachenuruka) - they remain stunted and chlorotic). The farmers reported a good yield response $\left(-0.5 \mathrm{t} \mathrm{ha}^{-1}\right)$ after liming, compared to total crop failure. Other legumes such as cowpea were generally regarded as minor and were often sparsely intercropped with maize or grown as sole crops on small pieces of land. According to farmers, extension staff do not recommend intercropping. They, however, reported a maizecowpea intercrop as successful and desirable. The only other legumes on the crops mentioned were bambara nut (Vigna subterranea (L.) Verdic.) and field bean (Phaseolus vulgaris L.). The legumes got relatively higher rankings from women who largely controlled their marketing and use at household level. The major reasons given for the low ranking of legumes were: (i) unavailability of seed; (ii) poor yields; and (iii) low prices on the market (this was however, dismissed by other farmers who knew the current prices). Group discussions revealed that trade on minor crops such as Bambara nut and field bean was mainly on a local scale as opposed to interdistrict or national scale, and this was mostly done by women. While men placed more emphasis on cash crops like cotton, women gave priority to food crops and other crops such as sunflower from which they are able to derive direct cash income after marketing.

Sources of external plant nutrients and their allocation to crops. Mineral fertiliser and manure were generally given the same ranking as nutrient sources (Tables 3 and 4). All groups reported better crop response after liming and revealed a general awareness of the low $\mathrm{pH}$ of soils. Leaf litter, mostly from miombo woodlands, was considered as another important source of crop nutrients, although it was said to be increasingly unavailable. Farmers using leaf litter, however, often travel long distances to collect it. For example, in Mukarakate East some farmers travel 
TABLE 3. Crop nutrient sources used by farmers in Mukarakate East Ward of Murehwa Communal Area, and how they were ranked by male and female farmers

\begin{tabular}{|c|c|c|c|}
\hline \multirow[b]{2}{*}{ Nutrient source } & \multicolumn{2}{|c|}{ Ranking by: } & \multirow[b]{2}{*}{ Reasons for preference and other attributes } \\
\hline & Men & Women & \\
\hline Animal manure & 1 & 1 & $\begin{array}{l}a \& b \text { more affordable though inadequate; }{ }^{a \& b} \text { people } \\
\text { paying more attention to it because of high fertiliser prices; } \\
a \& b_{\text {is only for livestock owners }}\end{array}$ \\
\hline Inorganic fertiliser & 1 & 2 & $\begin{array}{l}a \& b \text { one will always need it unless there are other nutrient } \\
\text { sources; } a \& b_{\text {no fertiliser no crop, }} b_{\text {cost }} \text { prohibitive }\end{array}$ \\
\hline Termitaria & 2 & 3 & $\begin{array}{l}a \& b_{\text {when spread in the field it makes soil heavier }} \\
\left(\text { kukodza ivhu); } a \& b_{\text {works over several seasons (>3); }}\right. \\
\text { brequires a lot of labour to spread }\end{array}$ \\
\hline Compost & * & 4 & $\begin{array}{l}b_{\text {very few people using it; }} b_{\text {requires too much labour to }} \\
\text { make }\end{array}$ \\
\hline Agricultural lime & 3 & 6 & 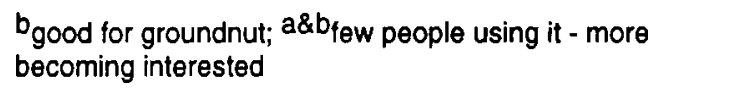 \\
\hline Rotation & 3 & & $\begin{array}{l}a_{\text {some crops do well when grown after others e.g maize }} \\
\text { after cowpea }\end{array}$ \\
\hline Leaf litter & 4 & 5 & $\begin{array}{l}b_{\text {women reckoned leaf litter was being used more than }} \\
\text { lime; } a_{\text {good but increasingly becoming unavailable }}\end{array}$ \\
\hline
\end{tabular}

" = not part of the list; $a=$ mentioned by men; $b=$ mentioned by women; ${ }^{a \& b}=$ mentioned by both sex

TABLE 4. Crop nutrient sources used by farmers in Mukarakate West Ward of Murehwa Communal Area, and how they were ranked by male and female farmers

\begin{tabular}{|c|c|c|c|}
\hline \multirow[t]{2}{*}{ Nutrient source } & \multicolumn{2}{|c|}{ Ranking by: } & \multirow[t]{2}{*}{ Reasons for preference and other attributes } \\
\hline & Men & Women & \\
\hline Animal manure & 1 & 2 & $\begin{array}{l}a_{\text {more affordable though inadequate, }} a \& b \text { more } \\
\text { effective after one season, } b_{\text {is only for livestock }} \\
\text { owners }\end{array}$ \\
\hline Inorganic fertiliser & 2 & 1 & $\begin{array}{l}b_{\text {most people aware of its benefits, }}{ }^{a \& b} \text { no fertiliser no } \\
\text { crop, } a_{\text {cost prohibitive }}\end{array}$ \\
\hline Termitaria & 3 & 4 & $\begin{array}{l}a \& b_{\text {environment good for sorghum and millets, }} \\
a \& b_{\text {works over several seasons }(>3), a \& b \text { requires a }} \\
\text { lot of labour to spread }\end{array}$ \\
\hline Compost & 4 & 3 & $\begin{array}{l}b_{\text {very few people using it, }} a_{\text {requires to much labour }} \\
\text { to make }\end{array}$ \\
\hline Leaf litter & 5 & 6 & $a \& b_{\text {increasingly becoming unavailable }}$ \\
\hline Agricultural lime & 6 & 5 & $\begin{array}{l}b_{\text {good for groundnut, }} a_{\text {\& }} b_{\text {few people using it - more }} \\
\text { becoming interested }\end{array}$ \\
\hline
\end{tabular}

$a=$ mentioned by men; ${ }^{b}=$ mentioned by women; $a \& b=$ mentioned by both sex 
about $4 \mathrm{~km}$ to mountains bordering a neighbouring resettlement area in search for litter. Participants also mentioned use of crop residues as a nutrient source (but only after further probing). Some farmers said they normally feed the residues to livestock, with the hope of getting greater manure output. Farmers considered groundnut and sunflower residues better than maize residues as nutrient sources. Only the men in Mukarakate East mentioned rotations as a source of nutrients. The women valued compost more than the men, and one male group failed to recognise it as a source of nutrients (Table 3 ). Compost was used by mostly women who applied it on the minor crops that they have control over.

In terms of nutrient allocation, it was perceived that maize took up to two-thirds of external nutrients (Table 5). In Mukarakate East, where more cotton was grown, the cotton crop accounted for about $20 \%$ of the nutrient inputs. Sunflower accounted for up to 15 percent of the amount of inputs in both wards. Legumes received noexternal inputs except for groundnut, which received up to $15 \%$, mostly lime. Three of the four farmer groups had difficulties accounting for contributions from rotations. According to farmers, there is one major difference between traditional and modern systems in terms of resource allocation strategies. Traditionally, particular crops would be allocated to particular environments on the basis of soil fertility, instead of 'taking nutrients to crops'. For instance, millets and sorghum were allocated to termitarium environments unlike nowadays when the termitaria soil is thinly spread over the whole field.

Factors limiting crop productivity. The main factors perceived as limiting soil fertility management were high inorganic fertiliser prices, lack of cash, the Economic Structural Adjustment Programme (ESAP), inadequate animal manure and lack of alternative soil fertility management options. Sentiments about inorganic fertilisers being 'harmful to soil' were again echoed. In both Wards, farmers estimated that between 40 and $50 \%$ of households did not own cattle. About half of those who own cattle were said to have less than five head. Composting was considered too labour intensive and leaf litter as hardly available. Although farmers said they generally did not fallow land due to small land holdings, it was revealed that $90 \%$ of farmers in Mukarakate West and $40 \%$ in Mukarakate East fallowed a piece of land in any one season due to poor soil fertility and lack of draught power. Farmers indicated that they would rather fallow their land, than establish a crop without any form of fertiliser. Farmers in Mukarakate West expressed their wish to stop using the recommended compound $\mathrm{D}$ fertiliser $\left(8 \% \mathrm{~N} ; 14 \% \mathrm{P}_{2} \mathrm{O}_{5} ; 7 \% \mathrm{~K}_{2} \mathrm{O}\right)$ and change to a "better type".

Performance of pigeonpea under farmermanaged experiment. The most notable feature was that farmers invariably allocated pigeonpea to some of their least productive plots in terms of

TABLE 5. Perceived nutrient allocation (percent) to major crops grown by families in Mukarakate area of Murehwa Communal area

\begin{tabular}{lccccc}
\hline Crop & \multicolumn{2}{c}{ Mukarakate East Ward } & & \multicolumn{2}{c}{ Mukarakate West Ward } \\
\cline { 2 - 3 } \cline { 5 - 5 } & Men & Women & & Men & Women \\
\hline Maize & 28 & 47 & 67 & 56 \\
Rapoko (Eleusine coracana) & 13 & 8 & 7 & 3 \\
Groundnut & 12 & 7 & 4 & 6 \\
Sunflower & 13 & 15 & 4 & 12 \\
Cotton & 18 & 8 & 0 & 8 \\
Cowpea & 0 & 0 & 0 & 0 \\
Bambara nuta & 1 & 0 & 0 & 0 \\
Field beana & $*$ & 10 & 3 & 0 \\
Garden crops & $*$ & $*$ & 3 & 10 \\
Sorghum & 12 & 3 & & 2 \\
\hline
\end{tabular}

" $=$ not listed; ${ }^{a}=$ minor crops (legumes) included for comparison 
soil fertility. All the soils tested were deficient in $\mathrm{N}$ and $\mathrm{P}$ (Table 6). There was high variability in crop performance between farms in both seasons (e.g. 1.6-3.7 t ha' ${ }^{-1}$ in the first season), most likely due to inherent variability between farms. On average, three times more shoot biomass was produced in the second season than in the first (Table 7). Biomass yields were 10 times more than the first season's yield when left to grow for two seasons. Measurements in the second season showed that about $8-9 \%$ of the total biomass was in form of litterfall, giving 723 and $2901 \mathrm{~kg} \mathrm{ha}^{-1}$ for 1- and 2-year old crops, respectively.

Despite the grazing of its stover by livestock, pigeonpea significantly increased yields of the subsequent maize crop, giving an average of $22 \%$ more grain than the control. There was high variability in application rates from one farm to another (Table 8). The highest maize yield responses were obtained where farmers used relatively high rates of mineral fertiliser on plots previously under pigeonpea.

\section{DISCUSSION}

Current role of legumes - importance of crop and gender interactions. Maize was considered the most important crop by all farmer groups in this study because of its dual role as a cash and staple food crop. There were some notable gender differences in the ranking of crops. The men were apparently concerned with cash crops while women placed emphasis on food crops. Rapoko (Eleusine coracana) was ranked second by both male groups, most likely because of its use during critical times of food shortage (it stores for a long time), and in ceremonial brews for which men, as heads of families, take responsibility. The main reason for the relatively higher ranking of legumes by women than men was the role of legumes as sources of relish and related foods. The low priority given to legumes by men, who are the prime decision-makers in these households, means that it is not easy for legumes to be given the priority they deserve. Although unavailability of land was cited as one reason for limited legume production, men's attitudes may be playing a major role. The lack of positive attitude may also hinge on men's readiness to positively respond to extension messages which, in turn, do not emphasise legumes. Indeed, COPIBO-Zimbabwe (1995) reported legumes as 'a women's affair.' This results in legumes being cropped on small land areas and traded mostly between neighbours

TABLE 6. Soil characteristics for plots used by farmers in a pigeonpea participatory experiment in Murewa, Zimbabwe

\begin{tabular}{lccccc}
\hline Farm & \% Clay & $\mathrm{pH}\left(\mathrm{CaCl}_{2}\right)$ & Resin $\mathrm{P}(\mathrm{ppm})$ & $\mathrm{N}(\mathrm{ppm})$ & \% Organic C \\
\hline Chirwa J. & 9 & 5.0 & 1 & 22 & 0.5 \\
Chokodza C. & 4 & 4.3 & 2 & 15 & 0.4 \\
Chirwanemhuka P. & 9 & 4.9 & 1 & 20 & 0.5 \\
Chikurunhe S. & 6 & 4.4 & 5 & 17 & 0.3 \\
Chikurunhe A. & 3 & 4.2 & 2 & 9 & 0.3 \\
Chawanda C. & 6 & 4.5 & 5 & 14 & 0.4 \\
Mukarakate K. & 5 & 4.6 & 8 & 21 & 0.4 \\
\hline
\end{tabular}

$\mathrm{N}=\mathrm{NO}_{3}{ }^{-}-\mathrm{N}$ and $\mathrm{NH}_{4}{ }^{+}-\mathrm{N}$ after incubation

TABLE 7. Mean pigeonpea biomass yields $\left(\mathrm{kg} \mathrm{ha}^{-1}\right)$ and cumulative litter fall ( $\%$ of total shoot biomass) under farmer managed conditions in Murewa, Zimbabwe

\begin{tabular}{llll}
\hline Growth duration & $\begin{array}{l}\text { Biomass yield } \\
1996 / 97 \text { season }\end{array}$ & $\begin{array}{l}\text { Biomass yield } \\
1997 / 98 \text { season }\end{array}$ & $\begin{array}{l}\text { Total litterfall (\%) } \\
\text { in 1997/98 season }\end{array}$ \\
\hline $\begin{array}{l}\text { One year's growth }(n=7) \\
\text { Growth after 2 years }(n=4)\end{array}$ & $\begin{array}{l}2768(344) \\
\text { nd }\end{array}$ & $\begin{array}{l}9039(1168) \\
23988(2222)\end{array}$ & $8(0.5)$ \\
\hline
\end{tabular}


(particularly women) and thus, making little impact on soil fertility. One of the main challenges to current research initiatives is to understand the role that legumes play within farming systems and to promote them where appropriate. Our study suggests that the allocation of major factors of production such as land and labour, and the distribution of the subsequent benefits from agriculture are dominated by men. Thus, despite contributing $60-90 \%$ of agricultural labour (Cashman, 1991), women may remain invisible in agriculture and their potential contribution to sustainable crop production undermined.

Studies in Lesotho, Sierra Leone and Kenya have shown that most of the major farm decisions are made by males even if they are non-resident (e.g., migrant husbands) (Safilios-Rothschild, 1985). Because of men's emphasis on immediate cash benefits, crops such as maize and cotton may continue to dominate the farming systems, despite factors such as poor productivity and low food security. Balancing gender interests and participation at household level may positively influence legume production. Farmers in this study were ignorant of current marketing opportunities and prices for legumes, suggesting lack of information. Like rapoko, the production of groundnut is apparently more of a tradition than a result of a coordinated technical intervention. The stuntedness and chlorosis reported for groundnut suggest poor nodulation and nitrogen deficiency. The crop is therefore unlikely to make a significant contribution to the $\mathrm{N}$ requirements of the cropping system.

The legumes are grown with very little or no fertiliser inputs, further emphasizing their minor role in the cropping system. This was confirmed during experimentation as all participating farmers did not fertilise pigeonpea. Only one of the four farmer groups mentioned rotation as a possible source of nutrients. Given the high level of farmer awareness of the low fertility of their soils, nonexploitation of the legume-cereal rotations suggests that the benefits of such rotations have not been well demonstrated or adequately emphasised. It seems that biological nitrogen fixation is simply regarded as a bi-product of legume production and not as one of the principal outputs of the production system.

Disadvantages of the current management practices. Concern by farmers about : lack of residual effects from inorganic fertilisers does not only show farmers' awareness of the declining soil productivity, but also strongly points towards the need for increasing soil organic matter (SOM) for sustainable soil fertility management. Use of inorganic fertilisers in maize monoculture has undoubtedly resulted in depletion of soil nutrients as well as destruction of soil physical properties. The decline in SOM under such cropping systems are well known (Grant, 1981; Kumwenda et al., 1995). The general farmer perception that inorganic fertilisers "kill the soil" may be strongly

TABLE 8. N, P and K fertilisers applied and maize yields achieved by different farmers in the 1997/98 season under pigeonpea-based rotations in Murewa, Zimbabwe

\begin{tabular}{|c|c|c|c|c|c|}
\hline \multirow[t]{2}{*}{ Farm } & \multicolumn{3}{|c|}{ Fertilisers applied (kg ha-1) } & \multicolumn{2}{|c|}{$\begin{array}{l}\text { Maize yields }\left(\mathrm{kg} \mathrm{ha}^{-1}\right) \text { obtained after maize } \\
\text { or pigeonpea }\end{array}$} \\
\hline & $\mathbf{N}$ & $\mathbf{P}$ & $\mathrm{K}$ & Maize & Pigeonpea \\
\hline Chirwa J. & 20 & 6 & 6 & 1818 & 2272 \\
\hline Chokodza C. & 17 & 6 & 6 & 588 & 400 \\
\hline Chirwanemhuka $P$. & 55 & 12 & 12 & 2333 & 2750 \\
\hline Chikurunhe S. & 55 & 15 & 15 & 2125 & 3250 \\
\hline Chikurunhe A. . & 30 & 6 & 6 & 625 & 650. \\
\hline Chawanda C. & 36 & 9 & 9 & 750 & 875 \\
\hline Mukarakate K. & 43 & 12 & 12 & 3750 & 4400 \\
\hline Mean & $37(6)$ & $9(1)$ & $9(1)$ & $1713(439)$ & $2085(568)$ \\
\hline
\end{tabular}


linked to the decline in SOM and soil $\mathrm{pH}$ promoted by continuous use of inorganic fertilisers. The preference by farmers to feed maize stover to cattle may be resulting in net removal of nutrients and organic matter from the fields. Although the nutrients may later be concentrated in the form of manure (Swift et al., 1989), the manure so produced is not necessarily returned to the same piece of land. Because of the nature of Zimbabwe's agricultural revolution (Rukuni and Eicher, 1994), the current extension packages have favoured the production of cereals (especially maize) at the expense of legumes. The highly skewed distribution of external nutrients in favour of maize also suggests an over-emphasis on maize. This has resulted in continuous use of the same fertiliser types, and lack of diversity in legume production.

\section{Potential place for pigeonpea in soil fertility} management. Cattle manure is often inadequate (Carter, 1993; Mugwira and Murwira, 1997) and is limited to the cattle owners. Results from this study suggest that over $50 \%$ of households have no access to manure or have inadequate manure. Other locally-derived organic fertilisers such as compost, woodland leaf litter and termitarium soil are inadequate to meet crop nutrient requirements for most farmers (Campbell et al., 1998). Farmers can greatly benefit from production of pigeonpea. Pigeonpea is drought tolerant (van der Maesen, 1990) and can therefore benefit a wide range of farmers, including those in semiarid areas. Pigeonpea biomass yields of $3-9 t$ $\mathrm{ha}^{-1}$ produced in a single season by farmers in this study shows the crop's potential under conditions of poor soil fertility and low inputs. Biomass yields of $<3 \mathrm{t} \mathrm{ha}^{-1}$ during the first season may have bcen due to waterlogging experienced in the area (see Mapfumo et al., 1999). Although the data from this experiment may not provide sufficient scientific evidence on potential contribution of pigeonpea to soil fertility, it clearly demonstrates that the crop's agronomic needs are not beyond the farmers' management capabilities. All farmers managed to adapt and practice proper pigeonpea agronomy (e.g., plant spacing, weeding etc.) to their cropping environment. Given the relatively high quality of pigeonpea litter (e.g., Palm, 1995; Mafongoya et al., 1998) and increasing scarcity of woodland litter revealed during PRA, the amounts of litter released by pigeonpea may significantly contribute to soil fertility. The ultimate contribution, however, will depend on whether the farmer management strategy is targeted at short- or long-term benefits. Our study suggests that a two-year pigeonpea crop may be more beneficial to soil fertility under depleted soil conditions. Studies in other parts of southern Africa have shown that pigeonpea integration into farming systems may be in form of annual rotations, alley cropping, improved fallows or fodder banks (Boehringer and Caldwell, 1989; Snapp et al., 1998). Location of grazing areas on depleted soils, as indicated during the PRA, most likely results in poor quality grazing and hence low quality manure. Production of pigeonpea as a high quality fodder crop can, therefore, make an indirect contribution to soil fertility.

Given the high variability in fertiliser inputs used by different farming households, it may be important to determine the potential for legumes such as pigeonpea in stabilizing maize yields. Lack of fertiliser in the wake of poor soil fertility was one major reason why farmers fallowed their land (no fertiliser, no crop). This practice gives an opportunity for use of green manures and improved fallows to restore fertility. High incidence of fallowing in Mukarakate West may be due to the higher sand content of soils in this area compared with soils in Mukarakate East. Soils in Mukarakate West were found to contain 2-4 percent clay while those in Mukarakate East had 5-9 percent clay (Mapfumo, unpublished data). Mudhara and Chibudu (1996) reported up to 35 percent of households fallowing part of their fields in the Mangwende area.

The study revealed a lack of a comprehensive extension package on legume production. Use of legumes as a direct solution in soil fertility management and as a component of food security has, therefore, not been addressed. According to farmers, groundnut is grown year after year even if it fails. In contrast, cowpea is regarded as relatively minor despite its superior performance to groundnut in both sole and intercropped systems. This highlights lack of technical advice in relation to: i) appropriate legumes for given environments and ii) marketing and other utilization opportunities. In semi-arid areas of Zimbabwe, a 
strong extension thrust has led to the increased production of small cereal grains (Ahmed et al., 1996) despite maize being the more preferred food crop. Farmers have already identified the need and potential for intercropping. Pigeonpea as an intercrop in these systems, therefore, is likely to be acceptable. Soil fertility was apparently not a major criterion during crop ranking, suggesting that pigeonpea is less likely to be adopted merely on the basis of its capacity to improve soil fertility. Farmer education on the marketing and home consumption opportunities may play a significant role in adoption. Its importance as a food crop was also evident during the course of this study.

The PRA methodology. For PRA gathering baseline information from target farmer groups was useful. It is probably more useful and convenient than formal diagnostic surveys because of its timely provision of information and an overview of farmers' perceptions and attitudes towards given technological initiatives. The PRA approach allows for maximum farmer-to-farmer interaction before research questions are fully developed and answered. This offers researchers some form of an interactive interface at which contextual misunderstandings can be easily identified and resolved. During the PRA, a number of issues which the researchers may not have thought of are usually raised.

\section{CONCLUSIONS AND RECOMMENDATIONS}

Low soil fertility was a major crop production constraint in the study area. The decline in SOM and soil $\mathrm{pH}$ have apparently led to the belief by farmers that use of inorganic fertilisers is responsible for the reduced soil productivity. Legumes are currently contributing very little to soil fertility in this cropping system. The legumes are largely a women's crop, and this attitude by men as major household decision makers has probably undermined adoption of legume' production. Empowering women to make decisions with respect to allocation of factors of production may enhance adoption of legumes. The over-emphasis of maize under the current extension packages has not only influenced men's attitude but also discouraged diversity in crop production. Farmer-led experiments demonstrated that farmers have the capacity to manage pigeonpea, and that the crop can accumulate sufficient biomass to influence soil fertility under poor soil conditions. Because of its versatility (protein source, fodder and fuelwood), pigeonpea can potentially benefit a wide range of farmers. However, successful adoption of pigeonpea and other legume-based technologies may largely depend on the involvement of women in decisionmaking. There is, however, need to enhance dissemination of information through extension approaches to both men and women on legume technology.

\section{ACKNOWLEDGEMENTS}

We thank the EU and IDRC for their financial support through the Institute of Environmental Studies of the University of Zimbabwe.

\section{REEERENCES}

Ahmed, M.M., Rohrbach, D.D., Gono, L.T., Mazhangara, E.P., Mugwira, L.; Masendeke, D.D. and Alibaba, S. 1996. Soil fertility management in the communal areas of Zimbabwe: Currentpractices, constraints and opportunities for changes. Results of a diagnostic survey. Southern and Eastern Africa Regional Paper number 6. ICRISAT-Southern and Eastern Africa Region. 27 pp.

Ali, M. 1996. Pigeonpea-based cropping systems in the semi-arid tropics. In: Dynamics of Roots and Nitrogen in Cropping Systems of the Semi-Arid Tropics. Ito, O., Johansen, C., AduGyamfi, J.J., Katayama, K., Kumar Rao, J.V.D.K. and Rego, T.J. (Eds.), pp. 41-58. Japan International Centre for Agricultural Sciences. Ibaraki 305, Japan.

Boehringer, A. and Caldwell, R. 1989. Cajanus cajan (L.) Millsp. as a potential agroforestry component in the Eastern Province of Zambia. Agroforestry Systems 9:127-140.

Breman, H. 1998. Soil fertility improvement in Africa, A tool for or aby-product of sustainable production. African Fertilizer Market 11:210. 
Campbell, B.M. 1994. The environmental status of the Save catchment. In: Wetlands Ecology and Priorities for Conservation in Zimbabwe. Matiza, T. and Carter, S.A. (Eds.), pp. 21-24. IUCN, Gland, Switzerland.

Campbell, B., Grundy, I. and Matose, F. 1993. Tree and woodland resources - the technical practices of small-scale farmers. In: Living with Trees: Policies for Forestry Management in Zimbabwe. Bradley, P.N. and McNamara, N. (Eds.), pp. 29-62. World Bank Technical Report number 210. Washington D.C.

Campbell, B.M., Frost, P., Kirchmann, H. and Swift, M.J. 1998. A survey of soil fertility management in small-scale farming systems on north eastern Zimbabwe. Journal of Sustainable Agriculture 11:19-39.

Carter, S.E. 1993. Soil fertility management in Mutoko Communal,Area, Zimbabwe. Report of a field exercise, August 12 - September 3 1992. TSBF, Nairobi.

Carter, S.E. and Murwira, H.K. 1995. Spatial variability in soil fertility management and crop response in Mutoko Communal Area, Zimbabwe. Ambio 24:77-84.

Cashman, K. 1991. Systems of knowledge as systems of domination: The limitation of established meaning. Agriculture and Human Values 8:49-58.

Chambers, R., 1992. Rapid Appraisal: Rapid, Relaxed and Participatory. Institute of Development Studies discussion paper 311. University of Sussex, England. 90 pp.

COPIBO-Zimbabwe, 1995. Socio-economic Study of Agriculture and Horticulture in Zimbabwe: Background Information for Biotechnology Research and Revelopment Projects. COPIBO-Zimbabwe, Harare. 116 pp.

David, S. 1997. Household economy and traditional agroforestry systems in western Kenya. Agriculture and Human Values 14:169-179.

FSRU. 1994. Sustainable land management systems. Special Report. Department of Research and Specialist Services, Harare. $60 \mathrm{pp}$.

FSRU. 1993. Soil Fertility Management by Smallholder Farmers: A Participatory Rapid
Appraisal in Chivi and Mangwende Areas, Zimbabwe. Department of Research and Specialist Services, Harare, Zimbabwe. 27 pp.

Giller, KE., McDonagh, J.F. and Cadisch, G. 1994. Can biological nitrogen fixation sustain agriculture in the tropics? In: Soil Science and sustainable land management in the tropics. Syers, P.K. and Rimmer, D.L. (Eds.), pp. 173191. C.A.B International, Wallingford, UK. Grant, P.M. 1967. The fertility of sandveld soil under continuous, cultivation. Part I. The effect of manure and nitrogen fertilizer on the nitrogen status of the soil. Rhodesia Zambia Malawi Journal of Agricultural Research 5: 71-79.

Grant, P.M. 1981. The fertilization of sandy soils in peasant agriculture. Zimbabwe Agricultural Journal 78:169-175.

Kumwenda, J.D.T., Waddington, S.R., Snapp, S.S., Jones, R.B. and Blackie, M.J. 1995. Soil Fertility Management for Smallholder MaizeBased Cropping Systems of Southern Africa: A Review. Network Working Paper No. 1. Soil Fertility Network for Maize-Based Cropping Systems in Countries of Southern Africa. CIMMYT, Harare, Zimbabwe. $34 \mathrm{pp}$. Mafongoya, P.L., Giller, K.E. and Palm, C.A. 1998. Decomposition and nitrogen release patterns of tree prunings and litter. Agroforestry Systems 38: 77-97.

Mapfumo, P., Giller, K.E., Mpepereki, S. and Mafongoya, P.L. 1999. Dinitrogen fixation by pigeonpea of different maturity types on granitic sandy soils in Zimbabwe. Symbiosis 27:305-318.

Mapfumo, P. and Mtambanengwe, F. 1999. Nutrient mining in maize-based systems of rural Zimbabwe. In: Proceedings of the Sixth Eastern and Southern African Regional Maize Conference, 21-25 September, 1998, Addis Ababa, Ethiopia. EARO-Ethiopia/CIMMYT, 1999. pp. 274-277.

Mapfumo, P., Mpepereki, S. and Mafongoya, P. 1998. Pigeonpea in Zimbabwe: A new crop with potential. In: Soil Fertility Research for Maize-Based Farming Systems in Malawi and Zimbabwe. Waddington, S.R., Murwira, H.K., 
Kumwenda, J.D.T., Hikwa, D. and Tagwira, F. (Eds.), pp. 93-98. Soil Fert Net and CIMMYT-Zimbabwe, Harare; Zimbabwe. Mudhara, M. and Chibudu, C. 1996. An overview of socio-economic issues and research into soyabean: A case study for Mangwende Communal Area. In: Soybean in Smallholder Cropping Systems of Zimbabwe: Potential contributions from biological nitrogen fixation. Mpepereki, S., Giller, K.E. and Makonese, F. (Eds.), pp 4-11. Proceedings of a Participatory Workshop, 8-9 February, 1996. University of Zimbabwe with Soil Fert Net, Harare. Zimbabwe.

Mugwira, L.M. and Murwira, H.K. 1997. Use of Cattle Manure to Improve Soil Fertility in Zimbabwe: Past and Current Research and Future Research Needs. Network Working Paper No. 2. Soil Fertility Network for MaizeBased Cropping Systems in Zimbabwe and Malawi. CIMMYT, Harare, Zimbabwe. 33 pp.

Nene, Y.L., and Sheila, U.K. 1990. Pigeonpea: Geography and importance. In: The Pigeonpea. Nene, Y.L., Hall, S.D. and Sheila, U.K. (Eds.), pp 1-14. C.A.B. International, UK, in collaboration with ICRISAT.

Palm, C.A. 1995. Contribution of agroforestry trees to nutrient requirements of intercropped plants. Agroforestry Systems 30: 105-24.

Rukuni, M. and Eicher, C.K. 1994. Zimbabwe' Agricultural Revolution. University of Zimbabwe Publications, Harare, Zimbabwe. $418 \mathrm{pp}$.

Safilios-Rothschild, C. 1985. The persistence of women's invisibility in agriculture: theoretical and policy lessons from Lesotho and Sierra Leone. Economic Development and Cultural Change 33: 299-313.

Sanchez, P.A. and Logan, T.J. 1992. Myth and science about the chemistry and fertility of soils in the tropics. In: Myths and Science of Soils of the Tropics. Lal, R. and Sanchez, P.A. (Eds.), pp. 34-46. SSSA Special Publication No. 29. ASA_CSSA-SSSA, Madison. WI, USA.
Swift, M.J., Frost, P.G.H., Campbell, B.M., Hatton, J.C. and Wilson, K.B. 1989. Nitrogen cycling in farming systems derived from savanna: Perspectives and challenges. In: Ecology of Arable Land. Clarholm, M. and Bergstrom, L. (Eds.), pp. 63-76. Kluwer Academic Publishers.

Thies, J, and Grady, H.M. 1991. Participatory RapidAppraisalfor Community Development: A training manual based on experiences in the Middle East and NorthAfrica. International Institute of Development Studies/Save the Children, UK. 150 pp.

Tuwafe, S., Silim, S.N. and Singh, L. 1994. ICRISAT/AfDB Pigeonpea Improvement Project in Eastern and Southern Africa. In: Improvement of Pigeonpea in Eastern and Southern Africa: Annual research planning meeting 1993. Silim, S. N., Tufuwe, S. and Singh, L. (Eds.), pp. 10-18. Bulawayo, Zimbabwe.

van der Maesen, L.J.G. 1990. Pigeonpea: Origin, history, evolution and taxonomy. In: The Pigeonpea. Nene, Y.L., Hall, S.D. and Sheila, U.K. (Eds.), pp. 15-46. C.A.B. International, UK in collaboration with ICRISAT.

van Reuler, H. and Prins, W.H. 1993. The role of plant nutrients for sustainable food production in Sub-Saharan Africa. Dutch Association of Fertilizer Producers, The Netherlands. 232 pp.

Waeterloos, E., Guveya, E., Mapfumo, P. and Chikunya, S. 1993. A Rapid Rural Appraisal of the Selected Survey Areas. UZ/UFSIABelgium Lupin Research Project working paper 7.

Whiteman, P.C., Byth, D.E. and Wallis, F.S. 1985. Pigeonpea (Cajanus cajan (L.)). In: Grain Legume Crops. Summerfield, J.R. and Roberts, E.H. (Eds.), pp. 558-598. Collins, London.

Whitlow, J.R. 1980. Land use, population pressure and rock outcrops in the Tribal Areas of Zimbabwe Rhodesia. Zimbabwe Rhodesia Agricultural Journal 77: 3-11. 